This item was submitted to Loughborough's Research Repository by the author.

Items in Figshare are protected by copyright, with all rights reserved, unless otherwise indicated.

\title{
Sustaining livelihoods by improving urban public transport
}

PLEASE CITE THE PUBLISHED VERSION

PUBLISHER

(C) Thomas Telford Publishing

LICENCE

CC BY-NC-ND 4.0

\section{REPOSITORY RECORD}

Sohail, M.. 2019. "Sustaining Livelihoods by Improving Urban Public Transport". figshare. https://hdl.handle.net/2134/3888. 
This item was submitted to Loughborough's Institutional Repository (https://dspace.lboro.ac.uk/) by the author and is made available under the following Creative Commons Licence conditions.

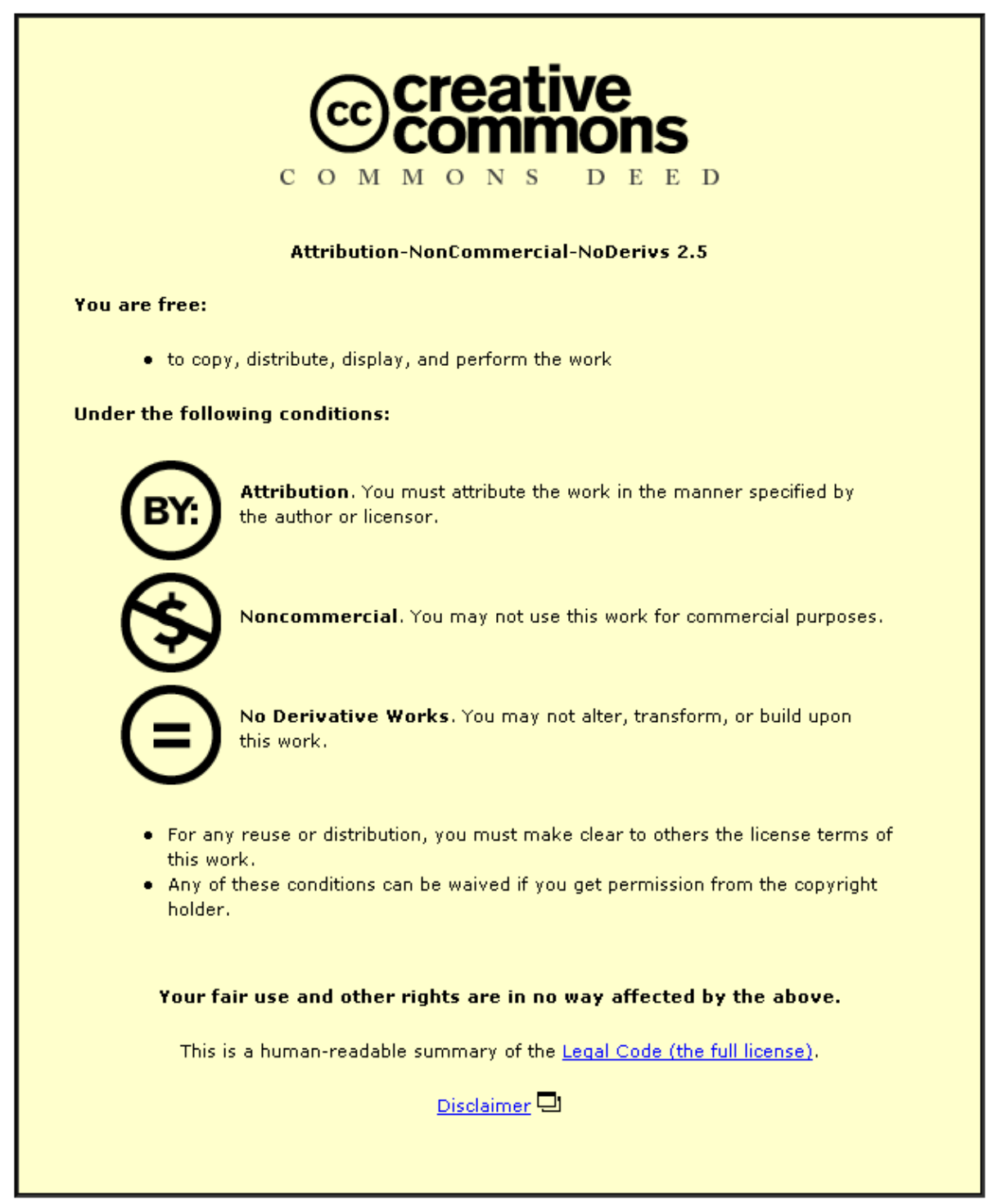

For the full text of this licence, please go to: http://creativecommons.org/licenses/by-nc-nd/2.5/ 


Proceedings of the Institution of
Civil Engineers
Engineering Sustainability I 58
March 2005 Issue ESI
Pages $9-15$
Paper 13794
Received 29/03/2004
Accepted $16 /$ I I/2004
Keywords:
developing countries/social impact/
sustainability/transport planning

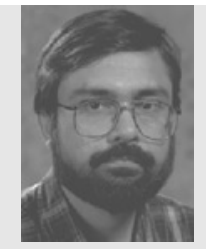

Muhammad Sohail Senior Research Manager, Water, Engineering and Development Centre, Loughborough University, UK

\section{Sustaining livelihoods by improving urban public transport}

\section{Sohail PhD, MSc, MASCE}

This paper reports on application of the Sustainable Livelihoods Approach to the wider impacts of urban public transport on the lives of the urban poor in developing countries. In applying the Sustainable Livelihoods Approach to the research data, transport is considered as an asset within the Sustainable Livelihoods framework. It draws upon findings of case studies undertaken between $200 \mathrm{I}$ and 2003 in Colombo (Sri Lanka), Faisalabad (Pakistan) and Dar-es-Salaam (Tanzania). Using a combination of quantitative and qualitative data, the study looks at price, affordability, accessibility and quality of public transport services.

\section{INTRODUCTION}

Eradication of poverty and enhancing access to health, education, water supply, sanitation and to shelter were identified as Millennium Development Goals (MDGs) by the United Nations in 2000. These are now significant objectives of international development policy and are the targets against which progress is measured. Concerted efforts are therefore ongoing for enhancing urban infrastructure in countries where the growing urban population and rate of urbanisation are creating unprecedented pressure on both access to and quality of urban services such as water, sanitation, health, education and public transport. The quality of life for all, particularly the poor, is dependent on these urban services. There is also increasing demand for better communications and mobility.

Urbanisation in countries in Africa and Asia, where efforts are concentrated for meeting the MDGs, is accompanied by economic growth in the formal and informal sectors. In many of these countries, the construction and transport sectors are a major source of employment for unskilled urban workers. The transport sector is associated with direct improvements in physical capital, such as improvements in pavements and bus stations. However, access to transport and other services such as schools, health clinics and markets is integral and contributory to the indirect development of all capital assets. For relatively short journeys, travel on foot is the popular travel mode but as journey distances increase, public transport is the only available mode of travel for the poor. Equally, the transport sector (both formally and informally) provides employment opportunities to many poor people in cities. The contribution of public transport to livelihoods includes access to employment and income-generation opportunities, education, health, and social networks, such as extended families.

Although transport plays an important role in the lives of all city inhabitants, studies on infrastructure and urban service provision primarily focus on direct impacts. This paper contends that the Sustainable Livelihoods Approach can best capture some of the indirect and wider socio-economic impacts in these sectors.

A historical and socio-economic context is necessary, along with an understanding of practical realities, if policies are to be translated into actions on the ground. It is therefore proposed that an integrated and holistic approach rather than a sectoral approach is taken to identify the key policies and practices for improving the livelihoods of the poor.

\section{TRANSPORT AND THE POOR}

Access to sustainable and affordable transport is critical for the urban poor, as it offers a way out of economic, social and physical isolation. It is also a key link to access other services and livelihood assets. Access to transport influences the assets available to a community and its inhabitants, and is in turn influenced by an individual's or a community's assets. For example, a person may be employed in the transport sector, or his/her employment (and hence financial assets) may be influenced by access to public transport. Likewise, the person's financial assets will influence whether or not he/she is able to afford public transport. In the same way, a community's natural assets (local terrain, climate, etc.) influence the cost of transport provision, while transport infrastructure and vehicles impact the natural environment in terms of noise, pollution, etc.

A sustainable approach to planning, implementation, and operation of infrastructure projects in urban areas can contribute towards sustainable livelihoods and poverty reduction. Hence, transport practitioners have a significant role to play in understanding and supporting sustainable livelihoods as part of a multi-sectoral analysis of community life.

\section{I. Demand for research on the impact of transport on livelihoods}

Currently, there is little understanding about how services such as public transport contribute to sustaining livelihoods of the poor. ${ }^{1}$ Research findings by Sohail et al. ${ }^{2}$ contribute to the knowledge 
base by focusing on policy and operational-level issues to establish the nature of the link.

The Sustainable Livelihoods Approach is based on the work of Chambers and Conway, ${ }^{3}$ who define it as follows

'A livelihood comprises the capabilities, assets (stores, resources, claims and access) and activities required for a means of living: a livelihood is sustainable which can cope with and recover from stress and shocks, maintain or enhance its capabilities and assets, and provide sustainable livelihood opportunities for the next generation; and which contributes net benefits to other livelihoods at the local and global levels in the long and short term.'

This paper is based on the premise that a better understanding of the inter- and intra-linkages of public transport and its impact on the sustainable livelihoods of the poor is necessary. It reports on the application of the Sustainable Livelihoods Approach to urban public transport through introduction of the Sustainable Livelihoods framework wherein public transport was integrated as an asset within the framework. Fundamental to the work was the identification of key stakeholders, understanding roles and responsibilities, and analysing the working linkages and mechanisms used to deliver public transport services.

It draws upon the findings from Phase 2 of a Department for International Development (DFID)-funded project that was undertaken between 2001 and 2003 in three cities in three countries: Colombo in Sri Lanka, Faisalabad in Pakistan and Dar-es-Salaam in Tanzania. ${ }^{4-6}$ (Phase 1 comprised study in a single city, namely Karachi, where the research methodology was developed. ${ }^{7}$ ) In this context, public transport was defined as the provision of formal and informal transport that is consumed collectively (whether provided by the state or private sector) and a fare is paid by passengers. Public transport modes comprise trains, buses and minibuses, and include taxis, trams, trolleys, metros and para-transport modes such as rickshaws, bicycles and motor-cycle taxis. The study looked at price, affordability, access and quality in provision of public transport services and explored the following issues in the case-study cities.

(a) How can a methodology be developed using a Sustainable Livelihoods framework?

(b) How can the method be tested?

(c) How is it possible to indicate the links between the urban public transport and the livelihoods of the poor?

(d) How can the Sustainable Livelihoods framework be further refined and developed?

(e) What are the implications for policy and practice?

The project was reported in Reference 2 . Table 1 gives a profile of the case-study cities.

\section{METHODS AND SCOPE OF ENQUIRY}

The predominant 'how and why' nature of the DFID-funded research led to a case-study approach. It was understood at the outset that although case studies would not generate statistically representative generalisations, they would contribute to the logical explanation of events based on both quantitative and qualitative data. ${ }^{8,9}$
The study locations, Faisalabad (Pakistan), Colombo (Sri Lanka) and Dar-es-Salaam (Tanzania) provided a variability of situations and hence allowed rigorous testing of the findings. All the locations represent urban areas with a significant number of poor people and differences in local environments and the transport sector. Differences included the availability of different modes of transport, sheer numbers of private operators, different levels of use of motorised transport, differences in the proportion of people that have access to public transport services, and different cultural contexts. Such differences enabled the collection of a rich database.

For example, in Dar-es-Salaam, which has only privately operated minibuses and taxis, the poorest use minibuses while a high proportion can only afford to walk for most of their travel needs. It is important to understand the reasons for this including how the poor can gain access to public transport services and how the quality of public transport can be improved. The emphasis on access versus quality may differ from case to case. In terms of people who can only afford to walk and their access to public transport, the waiting times and availability of affordable routes are significant factors. More generally, most passengers have to walk significant distances either to or from bus stops or terminals. This factor was also included under 'access' to public transport vehicles.

Both quantitative and qualitative approaches were used to obtain the views of users, operators and regulators. The study methodology developed in Karachi was adapted and refined to the case-study areas. Research techniques included a travel diary, literature reviews, historical analysis, case studies, interviews, focus group discussions, forums and workshops. The attendees of focus group discussions, forums and workshops comprised users, including men, women, children, the elderly and disabled members of the community, operators and regulators.

Each case study comprised analysis of policies and strategies that govern public transport in the city, situational analysis of current issues, including identification of the key issues and formal and informal partnerships to improve the access and quality of public transport, and the issues for an improved transport system in the future.

The key viewpoints were sought in the context of the sustainable livelihood approach from users, particularly lowincome households, providers and operators of the services, such as bus companies, drivers' associations, owners' associations, etc., and from regulatory agencies (primarily the transport ministry concerned and other government agencies and the private bus companies). Views of the municipal traffic departments, city traffic police who regulate the traffic and licensing authorities were also taken. Approximately 300 interviews were conducted with key informants that included community leaders of low-income settlements, leaders of passenger societies, advisory members of the traffic and transport committee of the municipality, transport commission officials, members of professional organisations and interest groups, traffic police, members of municipal councils, and senior citizens groups. Fifteen forums, three city-level workshops and one international workshop were held. Several sources of secondary data, including unpublished reports, were reviewed during the study. 


\begin{tabular}{|c|c|c|c|}
\hline & Colombo, Sri Lanka & Dar-es-Salaam, Tanzania & Faisalabad, Pakistan \\
\hline Population (Est'd 2000) & 690000 & 2347000 & 2232000 \\
\hline $\begin{array}{l}\text { Poor as a } \% \text { of total } \\
\text { population }\end{array}$ & $50 \%$ & - & $40 \%$ \\
\hline \multirow{2}{*}{$\begin{array}{l}\text { No. case-study of } \\
\text { settlements }\end{array}$} & 6 & 3 & 4 \\
\hline & \multicolumn{2}{|c|}{ Issues of concern to the users } & \\
\hline Fares & $\begin{array}{l}\text { - Transport fares are affordable } \\
\text { for most people within the } \\
\text { selected communities }\end{array}$ & - Fares are very high & $\begin{array}{l}\text { - Very high transport cost } \\
\text { in proportion to incomes } \\
\text { and over-charging by } \\
\text { conductors }\end{array}$ \\
\hline Quality of services & $\begin{array}{l}\text { - Quality of the buses; } \\
\text { inadequate and poor } \\
\text { maintenance of infrastructure } \\
\text { such as bus-stops, shelters and } \\
\text { terminals, roads. } \\
\text { - Poor pedestrian facilities } \\
\text { aggravated by narrow, poorly } \\
\text { constructed and maintained } \\
\text { pavements that are blocked by } \\
\text { hawkers and motorists } \\
\text { - Long waiting time for boarding a } \\
\text { transport vehicle because } \\
\text { services are not properly } \\
\text { scheduled }\end{array}$ & $\begin{array}{l}\text { - Conditions at bus stops are } \\
\text { poor and unhygienic } \\
\text { - Respondents claimed that both } \\
\text { minibuses and larger buses } \\
\text { operate without timetables or } \\
\text { bus stops along the route } \\
\text { - Extreme congestion during } \\
\text { peak hours that is aggravated } \\
\text { by lack of bus-stops; there is } \\
\text { often undue traffic congestion } \\
\text { and degradation of roadside } \\
\text { pavements }\end{array}$ & $\begin{array}{l}\text { - Poor condition of roads and } \\
\text { unhygienic conditions of } \\
\text { buses } \\
\text { - Poor areas are not directly } \\
\text { linked to the main roads } \\
\text { - Local roads are in a very } \\
\text { poor condition } \\
\text { - Poor maintenance of } \\
\text { existing infrastructure }\end{array}$ \\
\hline $\begin{array}{l}\text { Sensitivity to the } \\
\text { vulnerable, including } \\
\text { women and children }\end{array}$ & $\begin{array}{l}\text { - Behaviour and attitudes of } \\
\text { drivers and crew, especially } \\
\text { towards women and children }\end{array}$ & $\begin{array}{l}\text { - Mistreatment of women, girls } \\
\text { and school-going children }\end{array}$ & $\begin{array}{l}\text { - Rude behaviour of drivers } \\
\text { and conductors of buses, } \\
\text { also towards women and } \\
\text { students. }\end{array}$ \\
\hline \multirow[t]{3}{*}{ General indiscipline } & $\begin{array}{l}\text { - Lack of regulation of fares and } \\
\text { indisciplined driving by three- } \\
\text { wheeler operators }\end{array}$ & $\begin{array}{l}\text { - Mini- and larger buses operate } \\
\text { without scheduled timetables } \\
\text { or bus-stops }\end{array}$ & $\begin{array}{l}\text { - Overcrowding of all modes } \\
\text { of transport during peak } \\
\text { hours }\end{array}$ \\
\hline & $\begin{array}{l}\text { - Passengers are unable to } \\
\text { channel their complaints to the } \\
\text { appropriate authorities for the } \\
\text { necessary action to be taken }\end{array}$ & $\begin{array}{l}\text { - Cycling is not feasible because } \\
\text { of narrow and congested roads, } \\
\text { reckless driving by vehicle } \\
\text { drivers and the hot and humid } \\
\text { climate }\end{array}$ & $\begin{array}{l}\text { - Buses neither stop at } \\
\text { scheduled bus-stops nor } \\
\text { ensure that passengers have } \\
\text { disembarked before moving } \\
\text { again }\end{array}$ \\
\hline & $\begin{array}{l}\text { - Competition among bus } \\
\text { drivers leads to reckless driving, } \\
\text { resulting in road accidents and } \\
\text { loss of life }\end{array}$ & - Vehicle drivers are reckless & $\begin{array}{l}\text { - Rash and excessively fast } \\
\text { driving }\end{array}$ \\
\hline
\end{tabular}

\section{SUSTAINABLE LIVELIHOODS APPROACH IN PRACTICE}

The approach of this research is that transport can best be viewed as an asset within the Sustainable Livelihoods framework. Access to transport influences the package of assets that is available to communities and the individuals within them. At the same time, access to transport is in turn influenced by those assets.

The Sustainable Livelihoods Approach is used by UK's DFID, the United Nations Development Programme (UNDP), Cooperative for Assistance and Relief (CARE), Oxford Committee for Famine Relief (Oxfam), and others with some differences. The common thread linking the agencies is their adoption of the work of Chambers and Conway, ${ }^{3}$ and partial adoption of their definition of livelihoods. ${ }^{10}$

DFID currently uses the Sustainable Livelihoods Approach as a framework to understand the dimensions of poverty and potential interventions for poverty reduction. In this context, 'livelihood' refers to the command an individual, family, or other social group has over an income or resources that can be used to satisfy its needs. Such resources may include information, cultural knowledge, social networks, and legal rights, as well as tools and other physical resources. Sustainability is considered to have environmental, social, economic and institutional aspects.

Key components of the framework for analysing the livelihoods of individuals and the community are

(a) capital assets

(b) the vulnerability context

(c) transforming structures (layers of organisations, both in the private and government sectors) and processes (laws, policies and incentives), which are now referred to as the policy, institutions and processes dimension.

Capital assets in the Sustainable Livelihoods framework, as identified in Fig. 1, are as follows.

(a) Natural capital: comprises natural resource stocks that are important for other resource flows, including land, water, wildlife, biodiversity and environmental resources. 


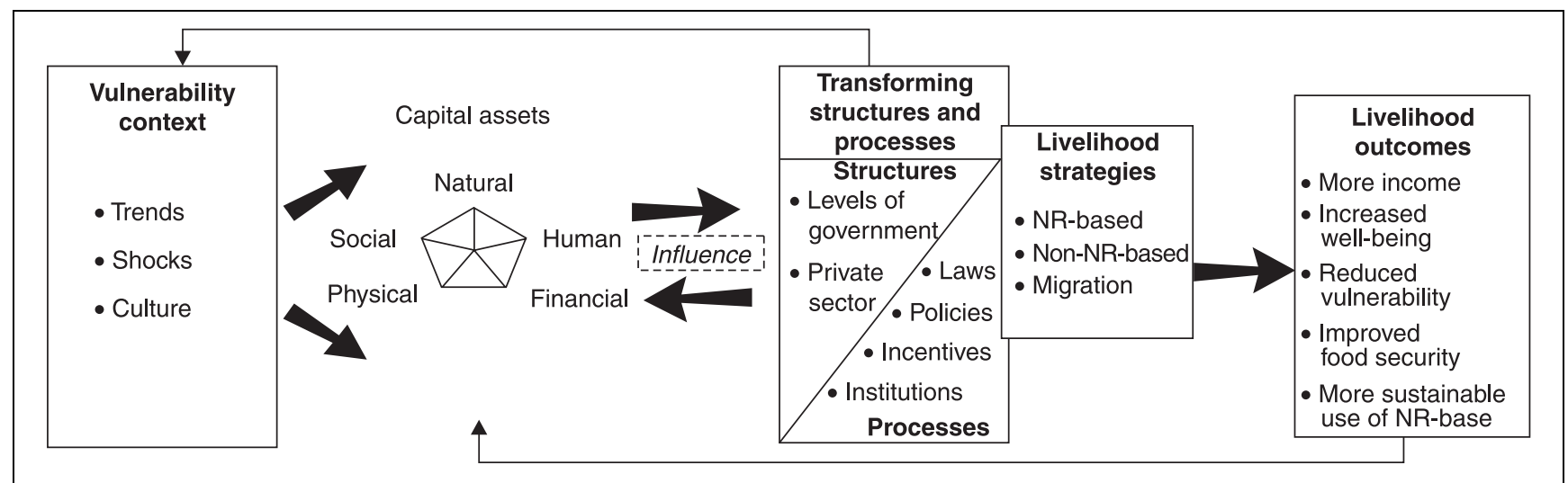

Fig. I Sustainable rural livelihoods: framework" (NR, natural resources)

(b) Social capital: comprises social resources that people draw upon in pursuit of livelihoods, namely networks, membership of groups, personal and business relationships and access to the wider institutions of society.

(c) Physical capital: includes basic infrastructure (transport, shelter, water, energy and communications) and the production equipment and means through which people pursue their livelihoods.

(d) Financial capital: includes financial resources available to people, including savings, supplies of credit or regular remittances or pensions, which provide them with different livelihood options.

(e) Human capital: incorporates skills, education, knowledge, ability to work and good health that are required if people are to pursue different livelihood strategies.

\section{INSIGHTS USING THE SUSTAINABLE LIVELIHOODS APPROACH}

Securing Sustainable Livelihoods depends on a number of cross-sectoral interventions, such as employment generation, health care and education facilities, access to adequate services, and reducing vulnerability with respect to accommodation, land tenure and so on. These components of a sustainable livelihood depend on the people having possession of various livelihood assets (human, social, natural, physical and financial capital) in order to achieve livelihood strategies, which are in turn determined by transforming structures (provided by government, the private sector, service providers and NGOs) and processes (laws, policies, culture and institutions). Individuals and communities, depending on their stock of assets, use these strategies to achieve livelihood outcomes such as, for example, increased well being and reduced vulnerability. ${ }^{12}$

The links between capital assets in the Sustainable Livelihoods framework and transport, and their influence on assets are listed in Table 2.

As highlighted in the table, transport affects the livelihood opportunities of the poor in many ways. What the table does not indicate is the relative importance of these different interactions. The research carried out in Colombo, Faisalabad and Dar-es-Salaam suggested the major influences to be those outlined below.

\section{I. Positive influences of transport}

5.1.1. Access to work, employment and income-generation opportunities. In the context of structural adjustment and liberalisation policies, there has been a reduction in the

\begin{tabular}{|c|c|c|}
\hline Assets & $\begin{array}{l}\text { Influence of assets on the } \\
\text { transport sector }\end{array}$ & $\begin{array}{c}\text { Anticipated influence } \\
\text { of transport services } \\
\text { on assets }\end{array}$ \\
\hline Natural & $\begin{array}{l}\text { - Terrain and climatic } \\
\text { conditions influence } \\
\text { costs of transport } \\
\text { provision and of } \\
\text { maintenance for } \\
\text { networks and of } \\
\text { services }\end{array}$ & $\begin{array}{l}\text { - Deterioration in quality } \\
\text { of local neighbourhood } \\
\text { environment-change } \\
\text { in degree of noise and } \\
\text { air pollution }\end{array}$ \\
\hline Social & $\begin{array}{l}\text { - Organisations bring } \\
\text { together transport } \\
\text { services, e.g. bus } \\
\text { provider associations } \\
\text { - Citizen pressure groups } \\
\text { impact decisions by } \\
\text { transport providers }\end{array}$ & $\begin{array}{l}\text { - Ease with which city- } \\
\text { based networks can } \\
\text { meet to negotiate with } \\
\text { local authorities } \\
\text { - Ease of maintaining } \\
\text { social networks to } \\
\text { strengthen social capital } \\
\text { - Access to social } \\
\text { networks needed for } \\
\text { financial services and } \\
\text { income generation }\end{array}$ \\
\hline Physical & $\begin{array}{l}\text { - Road and rail networks } \\
\text { that are critical to quality } \\
\text { of formal and informal } \\
\text { transport services } \\
\text { - Facilities for pedestrians }\end{array}$ & $\begin{array}{l}\text { - Allows access and } \\
\text { mobility to most areas of } \\
\text { urban centres and rail } \\
\text { links to national } \\
\text { locations }\end{array}$ \\
\hline Financial & $\begin{array}{l}\text { - Availability of credit and } \\
\text { investment finance for } \\
\text { transport-related } \\
\text { investments in the } \\
\text { informal and formal } \\
\text { sectors } \\
\text { - Ability to afford } \\
\text { transport services }\end{array}$ & $\begin{array}{l}\text { - Access to work, } \\
\text { employment and } \\
\text { income-generation } \\
\text { opportunities } \\
\text { - Access to social } \\
\text { networks needed for } \\
\text { financial services and } \\
\text { income generation }\end{array}$ \\
\hline Human & $\begin{array}{l}\text { - Quality of staff } \\
\text { undertaking services } \\
\text { and regulatory duties } \\
\text { - Informal entrepreneur } \\
\text { activities along transport } \\
\text { routes }\end{array}$ & $\begin{array}{l}\text { - Access to education and } \\
\text { health services } \\
\text { - Levels of stress, injury } \\
\text { and mortality from } \\
\text { travelling, and } \\
\text { congestion due to } \\
\text { pedestrian and motor } \\
\text { traffic on roads }\end{array}$ \\
\hline
\end{tabular}


proportion of the population employed in formal waged employment. The subsequent proliferation of informal work in trade and services has meant a restructuring of livelihoods and a diversification to reduce the risk of loss of income from one source. In addition, there has been increasing labour force participation by women and children. Access to public transport services allows urban poor households to participate in a multitude of activities, including small-scale trading and service provision, work in factories, and as casual labour and domestic workers. The mobility of the urban poor thus plays a role in this diversification of livelihoods.

5.1.2. Access to education and health services. Many low-income settlements, especially those on the periphery of cities, are very poorly served by public transport services. Moreover, reductions in social service expenditures by governments may have increased the distances that residents have to travel. Thus, well-planned and low-cost transport services can greatly improve access to education and health services. This is of direct assistance to households in securing and improving their livelihoods.

5.1.3. Access to social networks and relationships. The role of transport in linking rural and urban communities is very important. Cultural and family links (such as traditional ceremonies) are significant between such communities.

\subsection{Negative influences of transport}

5.2.1. Cost of transport services. The cost of transport is a major burden and often takes up a substantial proportion of household budgets. The Colombo study showed that households were spending $8 \cdot 9-12 \cdot 7 \%$ of their monthly income on transport services every month. Among these, those with the lowest incomes spent the highest percentage on transport. The Dar-es-Salaam study showed that petty traders spent about $1-29 \%$ of their gross weekly income on public transport, with the overall average being 7\%. In addition to these direct costs, households also incur indirect costs through transport use, particularly the time taken to travel using low-cost options.

\subsubsection{Reduction in the quality of the local environment. In some} low-income settlements, transport services can reduce the quality of the local environment with noise and air pollution causing possible long-term ill health and chronic illness within the localities. Users in Faisalabad and Dar-es-Salaam highlighted the poor hygiene conditions and overcrowding of buses.

\subsubsection{Accidents/fatalities due to traffic accidents involving} public transport. Increasing motorisation inevitably leads to growing numbers of fatalities and injuries on the road networks. Where public transport vehicles are involved (heavily laden minibuses or buses, for instance), many casualties can occur.

\subsubsection{Congestion on busy streets in urban areas. While the} availability of public transport improves sustainable livelihood opportunities, the increase in motorised vehicles has led to congestion, which is aggravated by stoppages at unscheduled places. This can have a negative effect on the local environment, especially where large numbers of buses are parked for loading and offloading passengers.

\section{FINDINGS}

\section{I. Employment creation in the context of asset creation}

Public transport contributed to employment creation and asset creation in all the case-study locations. Asset creation was observed at the household, community, city and national levels. In Colombo, in addition to the larger public transport vehicles, three-wheelers provide significant self-employment opportunities. In Dar-es-Salaam, 6000 of the 7500 privately owned buses are owned by single owners. In Faisalabad, there are multiple transport modes and self-employment opportunities.

\subsection{Asset creation is multi-sectoral}

The Sustainable Livelihoods Approach enabled the researcher to see beyond sectors, and aided in exploring the links between transport and other sectors. Effective and efficient transport helps not only in the provision of urban services, but also in the provision of social services such as health and education. In terms of other sector influences, advances in information technology affect transport, while construction activities depend on transport facilities for supplies of goods and materials.

\subsection{Direct and indirect impacts of transport}

From the perspective of the users, access to and quality of public transport are key considerations. The operators and financiers, meanwhile, depend on the transport business for their livelihoods. Each transport firm creates opportunities for employees and suppliers. The transport sector not only provides jobs directly to workers such as the driver and conductor, it also provides opportunities for automobile mechanics, small enterprises that provide services such as wheel repairs and oil changes and opportunities for people selling water to the passengers. Such benefits may be underestimated in conventional evaluation exercises, as many are part of the informal economy.

\subsection{Informal mechanisms to mobilise finances}

In many countries, neither transport nor construction has been given industry status; hence, they are excluded from availing facilities such as credit and insurance. In many cities, including those of the case studies, the role of insurance is crucial for many small entrepreneurs. Due to lack of formal facilities, innovation has come from the informal sector. A bus owners' association in Karachi, for example, is running an informal insurance system whereby bus operators pay premiums; in the case of an accident, the collected money is used to pay for damages. The informal sector also provides credit to entrepreneurs who are excluded from the formal money market. The formal sector could learn from these ongoing activities to expand its coverage and markets.

\subsection{Lobbies, platforms and transport}

Transport operators such as bus owners, taxi drivers and truck owners have, in the absence of an official platform on which to influence the policies, formed an influential lobby through transport associations. On many occasions, their attempts to influence policy become confrontational, often leading to strikes across a country or the burning of buses. However, these associations represent a useful source of social capital for 
transport providers. They also encourage consumers to themselves form a lobby when, for example, fares rise. It might well be argued that current power relations are not conducive to any real exchange of views among stakeholders. However, it cannot be denied that there exists an opportunity to streamline and improve such social capital into a more productive consultative environment. The city forums used during the research showed encouraging signs that stakeholders can sit around a table and talk.

\subsection{Government participation}

The local community can play a significant role in defining and monitoring service provision. The main point in this respect is that it is up to governments to contribute positively to ongoing processes initiated by both the private sector and the community.

\subsection{Inter-sectoral inter-linkages}

Public transport is the key urban service in terms of its contribution to the livelihoods of the urban poor. Hence, any improvement in urban transport services will also improve those livelihoods. Currently, the focus of the sector professional is at best on inter-service links within the same sector or a similar sector. The livelihoods approach provides a better opportunity to see the broader picture, while still focusing on the livelihoods of the poor.

Why and how people travel and how that contributes to their livelihoods, or how transport helps in undertaking the activities required for Sustainable Livelihoods, are some of the questions that can be addressed if the Sustainable Livelihoods Approach is adopted. Transport not only creates employment within the sector, it also creates and maintains opportunities in other sectors-in small enterprises that provide mechanical services, for example. Many jobs for the poor living on the outskirts of the city are also made possible due to some form of effective transport, as, for example, with the good transport links to the central market in Dar-es-Salaam that are used by small farmers on a daily basis.

\subsection{Policies and practice}

Many policies that try to encourage employment creation in the transport sector overlook realities on the ground. In many instances, policy making becomes an end in itself. The assumption of many such processes is that once a policy has been enacted into law, things will happen. Yet in many developing countries, as was confirmed by the case studies, the level of implementation of even criminal laws is not effective. This lack of policy implementation can be traced back to a lack of participation by real stakeholders during policy formulation. If a policy is not 'owned' by the people who will be affected by it, enforcement will be expensive. Policy congruence is also important. In some cases, an improvement by a particular policy intervention might be negated entirely by policies dealing with other sectors.

\subsection{Linking micro and macro considerations}

As in most other cities, the workforce in the case-study cities depends on public transport to reach its workplaces. Women, children and the elderly from the low-income settlements are among those who rely on public transport for their daily work. Where there is a lack of reliable, good-quality transport, there is a negative impact on livelihoods. In the case of women and girls, for example, harassment at bus stops and on the buses is common. However, there is a lack of appropriate regulation to deal with this problem.

\subsection{Partnerships/alliances}

Partnerships can take different forms: formal or informal; legally or socially enforced; between two sectors or within a sector; or between the public and private sectors. Partnerships are an alternative to supplying transport services either via a state-run organisation or entirely by the private sector. Some of these partnerships can be at the community level or between smallscale operators.

\section{RECOMMENDATIONS}

\section{I. Policy-level recommendations}

A number of specific policy decisions may eventually become unavoidable for timely delivery to urban transport services.

(a) A platform within the executive power needs to be established to represent the three main perspectives: those of users, regulators and operators. A single, allencompassing official, legal body (Urban Transport Authority) for dealing with transport overall may need to be created at the city or regional level. Such an authority will need to adopt a more holistic approach to develop, maintain and sustain an urban transport network.

(b) The interaction between transport and employment creation needs to be further explored, particularly the role of transport in supporting the micro-enterprise. The initiation of a participatory and continuous process of data collection and monitoring, interaction with all stakeholders, and localised planning and policy making needs to be taken up by the above-proposed urban transport body.

\subsection{Grass-roots-level partnerships between stakeholders}

The potential exists for developing solutions through partnerships, to overcome the constraints of limited resources and lack of effective governance. Stakeholders can take up certain small projects easily and rapidly. Some examples that emerged from the case studies are as follows.

(a) The building, repair and maintenance of bus stops by the private sector to create employment and enterprise opportunities.

(b) Maintaining the cleanliness of bus stops and the interior of vehicles can be made a private-sector service to further encourage small enterprises.

(c) The use of ergonomically sound standards for the interiors of vehicles would improve user satisfaction and safety levels.

(d) The working conditions of drivers and helpers (conductors), as well as their conditions of employment, should be improved.

(e) The informal economy can be recognised and better used to meet development targets and objectives.

( $f$ ) A platform should be established, where user complaints can be acted upon, including those from women, children, the disabled and the elderly.

(g) Monitoring systems should be put in place to capture the wider impact of transport on employment and enterprise development. 


\section{DISCLAIMER AND ACKNOWLEDGEMENTS}

This paper is based on an output of the DFID for the benefit of low-income countries. The views expressed are not necessarily those of DFID. An earlier version of part this paper was presented at the Works 2001 Conference in Johannesburg, South Africa. ${ }^{13}$

The contributions and support of the many people who have willingly shared their knowledge, opinions and their time to the development of this work are gratefully acknowledged. In particular, DFID for supporting the work; Dr Dave Maunder, TRL Limited, UK; Dr Diana Mitlin, International Institute for Environment and Development (IIED); and the local collaborators in the research: the Urban Resources Centre, Karachi; Mr Chularathna of Sevanathe Urban Resource Centre, Colombo; Mr Attaullah Khan, Faisalabad; and Dr Kombe, University of Dar-es-Salaam. Thanks also to Sharad Bala Joshi in helping the author respond to some comments.

Special thanks to the many passengers living in the case-study locations, who contributed to the research and provided their perspectives on the issues. The research team is greatly indebted to them.

\section{REFERENCES}

1. Bryceson D. F., Maunder D. A. C., Mbara T. C., Kibombo R., DAvis A. S. C. and Howe J. D. G. F. Sustainable Livelihoods, Mobility and Access Needs. Transport Research Laboratory, Crowthorne, 2003, TRL Report 544.

2. Sohail M., Mitlin D. and Maunder, D. A. C. Guidelines: Partnership to Improve Access and Quality of Public Transport. Water, Engineering and Development Centre, Loughborough University, 2003, ISBN 184380035 7, $130 \mathrm{pp}$.

3. Chambers R. and Conway G. Sustainable Rural Livelihoods: Practical Concepts for the 21 st Century. Institute of
Development Studies, Brighton, 1991, IDS Discussion Paper, 296, pp 7-8.

4. Sohail M. (ed.) Partnership to Improve Access and Quality of Public Transport. A Case Report: Colombo, Sri-Lanka. Water, Engineering and Development Centre, Loughborough University, 2003, ISBN 184380036 5, 94 pp.

5. Sohail, M. (ed.) Partnership to Improve Access and Quality of Public Transport. A Case Report: Dar-es-Salaam, Tanzania. Water, Engineering and Development Centre, Loughborough University, 2003, ISBN 184380037 3, 116.

6. SoHaIL M. (ed.) Partnership to Improve Access and Quality of Public Transport A Case Report: Faisalabad, Pakistan. Water, Engineering and Development Centre, Loughborough University, 2003, ISBN 184380038 1, 236 pp.

7. Sohall M. (ed.) Urban Public Transport and Sustainable Livelihoods for the Poor: A Case Study in Karachi, Pakistan. Water, Engineering and Development Centre, Loughborough University, 2000.

8. Hakim, C. Research Design Strategies and Choices in the Design of Social Research, Allen \& Unwin, London, 1987.

9. Yin, R. K. Applications of Case Study Research. Sage Publications, Thousand Oaks, USA, 1993.

10. Carney D., Drinkwater M., Rusinow T., Neefjes K., Wanmali S. and Singh N. Livelihoods Approaches Compared. Department for International Development, London, 1999.

11. Department for International Development. Sustainable Livelihoods Guidance Sheets. DFID, London, 1999.

12. Ashley C. and CARNeY D. Sustainable Livelihoods: Lessons from Early Experience. Department for International Development, London, 1999.

13. SoHAIL, M. Potential role of urban transport in assets and employment creation for the poor. Proceedings of the 1st International Conference on Employment Creation in Development, Witwatersrand, Johannesburg, South Africa, April 2001, 169-179.

\section{What do you think?}

To comment on this paper, please email up to 500 words to the editor at journals@ice.org.uk

Proceedings journals rely entirely on contributions sent in by civil engineers and related professionals, academics and students. Papers should be $2-5000$ words long, with adequate illustrations and references. Please visit www.thomastelford.com/journals for author guidelines and further details. 